\title{
A question of balance
}

\author{
The turmoil in the financial markets could lead to severe cost-cutting by governments, but US politicians \\ would do well to note the benefits of continued support for clean energy and climate policies.
}

$\Lambda$ s Nature went to press, a US\$700-billion rescue plan for the collapsing financial sector remained in limbo in the US Congress. Some such deal may yet be passed. If it is, it still may not be enough to stop the global economy from sliding into recession. Faced with the prospect of fresh outlays and declining revenue, the US government may soon be looking for ways to tighten its belt, a situation likely to be echoed in Europe and beyond. For science and technology, this could mean less money for basic research, education and clean energy, and could pose fresh threats to the long-promised climate legislation in the United States.

Those who favour cutbacks - or, in the case of climate regulations, not moving forward - will say such activities cannot be afforded. In some cases, they may well be right; scientists may have to gird themselves for flat budgets into the foreseeable future, and set their priorities accordingly. But there is a danger that the debate will be framed entirely in terms of costs, with no consideration of the benefits. Investment in areas such as research, education and clean energy are part of the foundations for long-term prosperity.

The good news in the United States is that both leading presidential candidates have made this connection, especially in the energy and climate arena. Neither the Republican candidate John McCain nor the Democratic candidate Barack Obama is selling climate regulation as an expensive moral obligation to the environment. Instead, both speak of the benefits of 'green-collar' jobs and energy security.

There are concerns that McCain might succumb to pressure from the far-right of his party and back away from his pledge to curb greenhouse-gas emissions through a cap-and-trade programme. But he has yet to do so. His advisers continue to advocate hybrid vehicles, for instance, as both a cheaper and cleaner alternative to the internal combustion engine and a way to make the United States less dependent on increasingly expensive foreign oil.

Obama has gone further, integrating energy and climate policy with his plan for revitalizing the US economy. He argues that green jobs tend to be domestic jobs, which means energy security goes hand-in-hand with economic development. This might be

dismissed as overly optimistic, given that the transition to clean energy won't be cheap, but there is little doubt that new industries will eventually rise in place of the old ones. In last week's first presidential debate, Obama also endorsed solid investments in science and technology generally.

It's refreshing to see that this political realignment has also taken hold in Congress. Efficiency and conservation, frequently played down as feel-good measures in the past, are now seen as critical components of the energy equation. The notion that the government can use its purchasing power to advance the development of clean vehicles has been heralded as a way of increasing energy security while addressing the long-term threat of climate change.

Such ideas, if implemented, will drive new investment in the years to come. It will take time for the world's financial institutions to rebuild
"The fundamental need to create a more sustainable energy infrastructure to power the globe will be as strong as ever, and the market will respond to that opportunity." themselves following the implosion on Wall Street. But the fundamental need to create a more sustainable energy infrastructure to power the globe will be as strong as ever. Eventually the market will respond to that opportunity.

It would be naive to assume that progress on these issues will be easy, even with vigorous leadership. Private investment in new technology has increased significantly in recent years - but so have global greenhouse-gas emissions. This makes it all the more important that Congress and the international community move quickly to establish a solid and predictable climate regulatory framework to carry the world beyond the Kyoto Protocol. The current market turmoil is due in part to a continuing crisis of confidence, so a little regulatory certainty on greenhouse gases might be welcome. It won't solve the financial crisis by itself, but it would help businesses, financial institutions and funding agencies place their bets on the future.

\section{Life after Zerhouni}

\section{The next $\mathrm{NIH}$ director must juggle stagnant budgets, unhappy grantees and investigative lawmakers.}

\section{T} he imminent departure of Elias Zerhouni as director of the US National Institutes of Health (NIH) in Bethesda, Maryland, leaves large shoes to fill. Zerhouni, who announced last week he will quit his post by the end of October (see page 570), managed the agency with a blend of vision, toughness and dedication even as it faced stagnating funding, ethical uproars and an explosion of knowledge in biomedical research. It is to his credit that he leaves the agency with far more friends than enemies, and with a well-earned reputation as a public servant who tirelessly maintained his integrity during the administration of President George W. Bush.

Whoever follows Zerhouni faces unenviable challenges. Stem-cell research remains stymied by an outdated presidential policy. The conflict-of-interest scandal continues as Senator Charles Grassley (Republican, Iowa) has reported troubling instances of extramural NIH researchers failing to report five- and six-figure payments from drug companies that could benefit from their research. And with 